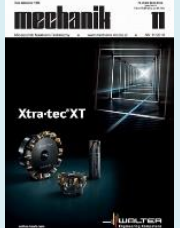

\title{
Influence of tool wear on the cutting torque and axial force in the milling of titanium alloy
}

\author{
Wpływ zużycia ostrza na moment skrawania i siłę bierną w procesie \\ frezowania stopu tytanu
}

\section{KAZIMIERZ ZALESKI \\ ANDRZEJ ZYŚKO JAKUB MATUSZAK *}

\begin{abstract}
The results of the survey on the influence of tool wear on the cutting torque and axial force in the milling of Ti6Al4V titanium alloy are presented. The tests were carried out by selecting cutting inserts with different degree of wear. The influence of the wear value on the flank surface and the cutting speed on the value of axial force and cutting torque is visible.
\end{abstract}

KEYWORDS: Ti6Al4V titanium alloy, tool wear, cutting torque, axial force

Titanium alloys, due to such properties as: very high specific strength (strength related to specific weight), corrosion resistance, high temperature operation and no harmful effects on the human body, are quite widely used in industry air, armament, ship, chemical, energy and transplantation [7, 8]. However, the drawback of these alloys, apart from a fairly high price, are the difficulties occurring during machining. They are associated with some of the properties of these materials, e.g. Iow thermal conductivity and high susceptibility to consolidation. Low thermal conductivity and high cutting forces affect the strong heating of the tools, which in turn causes their intensive wear.

The wear of the blades is affected by a number of factors. According to the authors of the work [5], the wear of the blades of sintered carbide inserts with which the Ti $6242 S$ alloy was milled depends on the technological parameters of machining, but is not significantly dependent on the coating covering the tile.

Studies on the wear of the blades of solid carbide milling cutters with a diameter of $\varnothing 6 \div 20 \mathrm{~mm}$ during the milling of the Ti6Al4V alloy have shown that with the increase of the cutter diameter there is a marked reduction in its wear [3].

The durability of the cutter blades also depends on the structure of the cemented carbide. It was found that the working time of milling cutters with ultra-fine grain structure is several times longer than those with coarse grain structure [4].

* Dr hab. inż. Kazimierz Zaleski (k.zaleski@pollub.pl), dr inż. Jakub Matuszak (j.matuszak@pollub.pl) - Katedra Podstaw Inżynierii Produkcji, Wydział Mechaniczny Politechniki Lubelskiej; mgr inż. Andrzej Zyśko - Wytwórnia Sprzętu Komunikacyjnego „PZL-Świdnik”
The components of the total cutting force in the titanium alloy machining process have quite large values, which is influenced by such factors as: high strength, susceptibility to consolidation and high coefficient of friction. Values and directions of forces affecting the workpiece have a large impact on the accuracy of the items being made due to the low longitudinal elasticity of titanium alloys.

The research of cutting force in the milling process of titanium alloys was most often carried out at variable technological parameters. In many works the influence of speed on the components of the cutting force was investigated.

The authors of the paper [2] stated that during the milling of thin-walled elements from the Ti6Al4V alloy with a variable cutting speed in the range of $v_{c}=60 \div 120 \mathrm{~m} / \mathrm{min}$, the resistance force $F_{\mathrm{y}}$ increases, and in the range $v_{\mathrm{c}}=$ $120 \div 180 \mathrm{~m} / \mathrm{min}$ the impact of velocity is clearly visible.

The study of the authors of the work [9] showed that the increase in cutting speed of the titanium alloy in the range of $v_{\mathrm{c}}=30 \div 40 \mathrm{~m} / \mathrm{min}$ contributes to a decrease in the cutting force, and a further increase in speed to $v_{\mathrm{c}}=60 \mathrm{~m} / \mathrm{min}$ does not affect the value of force. Comparative tests of the cutting torque during the alloying of OT4-1, Ti6AI4V, WT22 and WT3-1 titanium showed that WT22 alloy machining requires the use of the highest cutting torque. In addition, an increase in the cutting torque was observed along with the increase in feed, while increasing the cutting speed caused a decrease in the cutting torque amplitude [11].

In addition to determining the cutting force value using experimental methods, they can be predicted using the finite element method [1, 10]. Simulation tests of machining titanium alloys with a spherical cutter showed that there is a correlation between the components of the cutting force and the feed, while there is no relationship between these components and the cutting speed [1]. The comparison of the results of experimental and simulation studies of titanium alloy milling shows that the accuracy of the simulation tests using the finite element method depends to a large extent on the choice of the constitutive model of the processed material [6].

Previous studies of forces in the milling process of titanium alloys mainly concerned the impact of cutting parameters on the components of the total cutting force. The aim of the presentations was to assess the impact of the wear of the folding milling cutter on the cutting torque and reactive force during the milling of the titanium alloy in the scope of conventional and increased cutting speeds. 


\section{Research methodology}

The research experiment was carried out on the Avia VMC800HS vertical machining center, intended for machining in HSC conditions. Ti6Al4V titanium alloys with dimensions of $150 \times 90 \times 40 \mathrm{~mm}$ were used as the processed material. A two-fold cutter with a diameter of $\varnothing 20$ $\mathrm{mm}$ from Seco (symbol R217.21-1820.0-LP06.2A) with plates (LPHT060310ER - E05) made of sintered carbides in the MM4500 genre was used. Fig. 1 presents the research stand.

The changing factors during the milling process were tool wear (wear indicator on the $V B_{\max }$ application surface) and cutting speed $v_{c}$. Using a digital microscope, the consumption of plates was determined and plates were selected whose wear value on the application surface was $V B_{\text {max }}: 0 \mathrm{~mm}$ (new plates); $0.15 \mathrm{~mm} ; 0.30 \mathrm{~mm}$ and $0.45 \mathrm{~mm}$.

Fig. 2 shows examples of tiles with the assumed degree of wear.

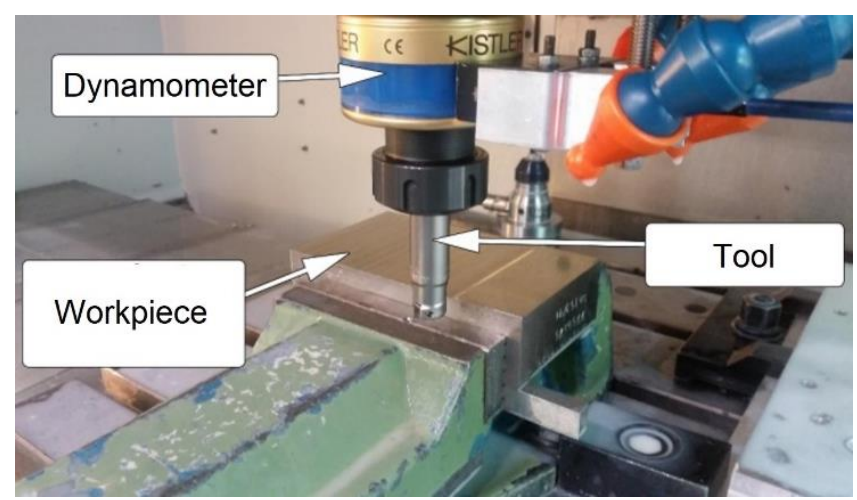

Fig. 1. Research stand

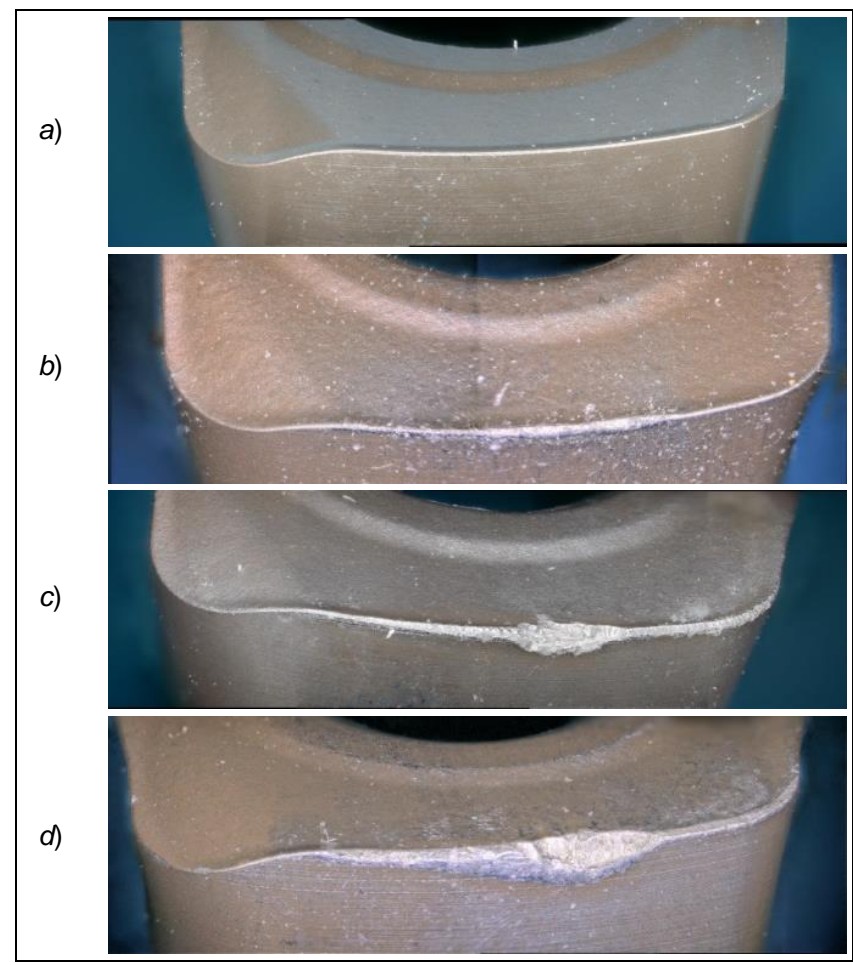

Fig. 2. Exemplary view of cutting inserts with varying degrees of wear body: a) $V B_{\max }=0 \mathrm{~mm}$; b) $V B_{\max }=0.15 \mathrm{~mm}$; c) $V B_{\max }=0.30 \mathrm{~mm}$; d) $V B_{\max }=0.45 \mathrm{~mm}$

Although the PN-ISO 8688 standard suggests that when the wear index $V B_{\max }>0.3 \mathrm{~mm}$ is exceeded, the blade should be qualified as worn, in industrial practice it is based mainly on intermediate indices, in particular with a technological character, such as: increase of surface roughness, exceeding dimensional tolerances or appearance of burrs on the edges of objects. Therefore, for tests, plates with $V B_{\max }=0.45 \mathrm{~mm}$ wear were tested. In the case of an increase in the wear indicator during the tests above $0.05 \mathrm{~mm}$, the plates were changed to avoid the impact of the increase in wear on the accuracy of the measurements.

Two cutting speeds were used:

- $v_{\mathrm{c}}=70 \mathrm{~m} / \mathrm{min}$ - this speed for this kind of workpiece is identified with the range of conventional values;

- $v_{\mathrm{c}}=250 \mathrm{~m} / \mathrm{min}$ - corresponds to the HSC treatment of the hard-to-beat titanium alloy Ti6Al4V.

A constant feed per blade $f_{z}=0.2 \mathrm{~mm} /$ blade and one depth of cut $a_{p}=0.5 \mathrm{~mm}$ was assumed. In order to avoid the influence of the cutting depth variable on the forces and cutting torque due to the non-perpendicular positioning of the machined surface in relation to the milling axis after the samples were clamped in the vice, the surface was planed with the head, determining the tool length with the use of a tool probe.

A traditional flooding method of cooling was used. The Kistler 9125A force gauge was used to measure reactive force (acting in the tool axis) and to the cutting torque. From the stable force course (bypassing the input zone of the tool into the material and exits from it), mean values and amplitudes of reactive force and cutting torque were determined. Amplitude is presented as the difference between the maximum values and the mean value. The study was repeated five times.

\section{Test results}

Fig. 3 shows an example of a signal waveform during cutting at $v_{\mathrm{c}}=250 \mathrm{~m} / \mathrm{min}$ with wear plates $V B_{\max }=0.3 \mathrm{~mm}$.

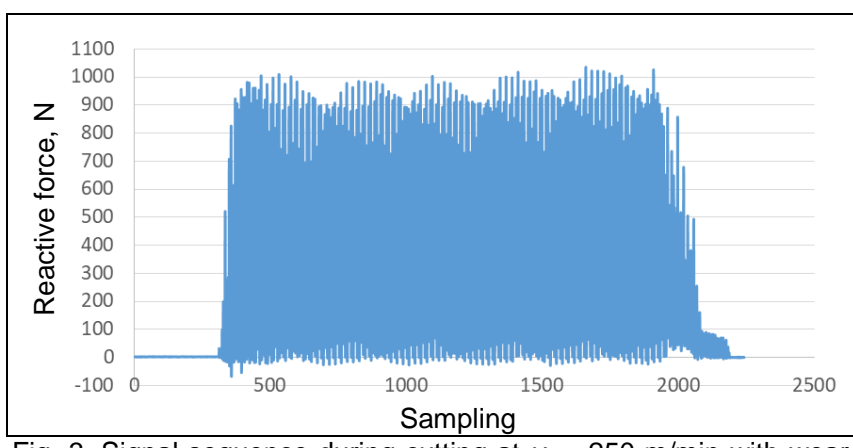

Fig. 3. Signal sequence during cutting at $v_{\mathrm{c}}=250 \mathrm{~m} / \mathrm{min}$ with wear plates $V B_{\max }=0.3 \mathrm{~mm}$.

Fig. 4 presents the results of tests on the impact of wear on the flank surface for various plates on the reactive power value during machining at the cutting speed $v_{\mathrm{c}}=70 \mathrm{~m} / \mathrm{min}$ and $250 \mathrm{~m} / \mathrm{min}$. Significantly lower values of reactive power are visible when machining was carried out with new plates in comparison with used plates.

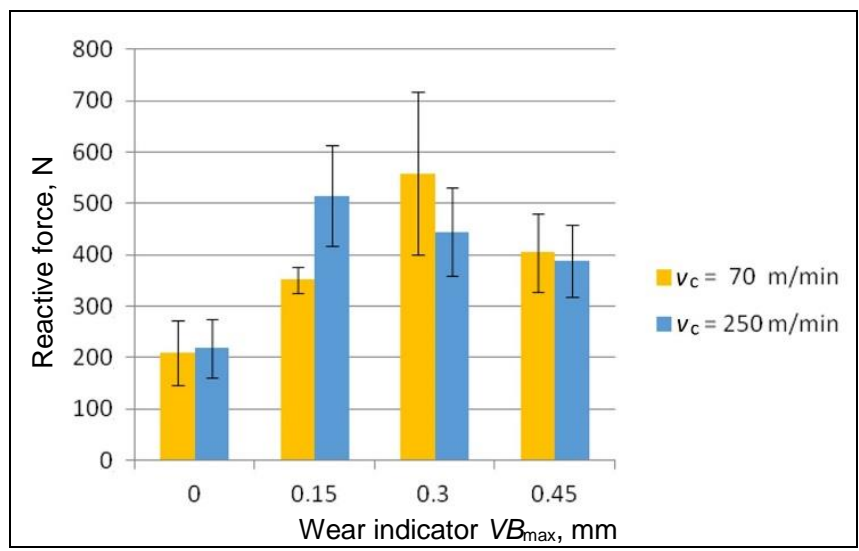

Fig. 4. Impact of wear on the reactive power value for velocity $v_{\mathrm{c}}=$ $70 \mathrm{~m} / \mathrm{min}$ and $250 \mathrm{~m} / \mathrm{min}$ 


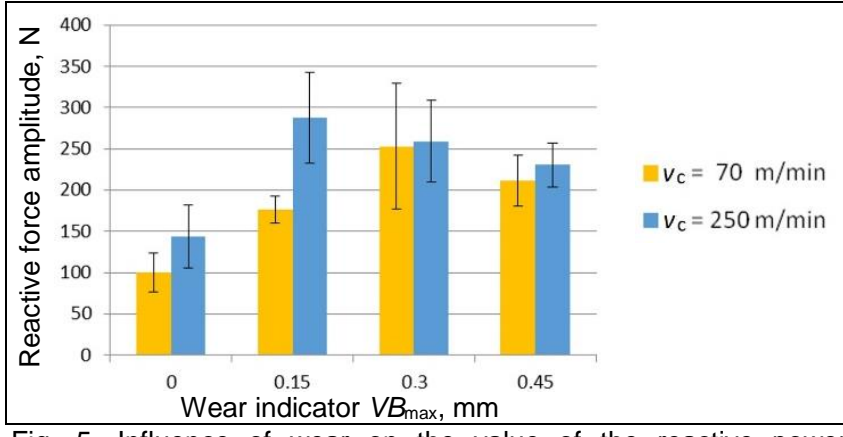

Fig. 5. Influence of wear on the value of the reactive power amplitude for velocity $v_{\mathrm{c}}=70 \mathrm{~m} / \mathrm{min}$ and $250 \mathrm{~m} / \mathrm{min}$

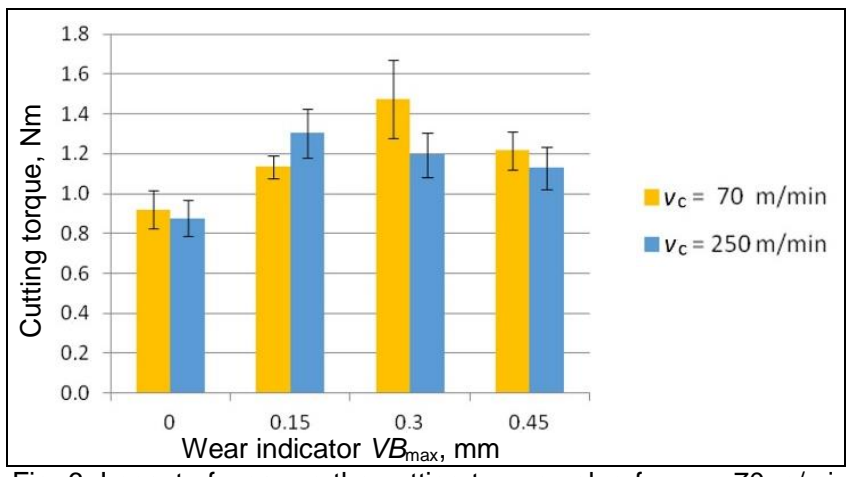

Fig. 6. Impact of wear on the cutting torque value for $v_{\mathrm{c}}=70 \mathrm{~m} / \mathrm{min}$ and $250 \mathrm{~m} / \mathrm{min}$

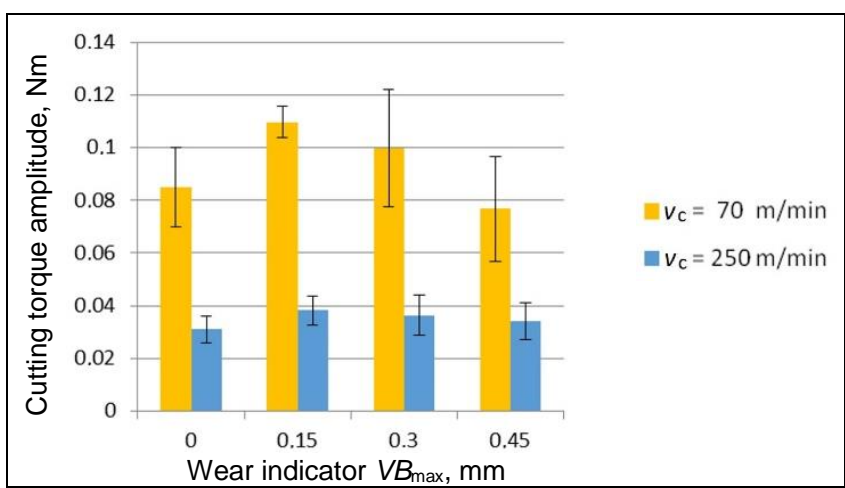

Fig. 7. Impact of wear on the value of the cutting torque amplitude for $v_{\mathrm{c}}=70 \mathrm{~m} / \mathrm{min}$ and $250 \mathrm{~m} / \mathrm{min}$

Fig. 5 shows the influence of wear on the amplitude of reactive power. For the cutting speed $v_{\mathrm{c}}=250 \mathrm{~m} / \mathrm{min}$, higher values of the reactive power amplitude were compared with the velocity $v_{c}=70 \mathrm{~m} / \mathrm{min}$. The amplitude of reactive force is characterized by quite large values in comparison with average values. Such large amplitude values are caused by the nature of the work of a two-edged cutter.

Fig. 6 presents the results of research on the impact of wear on the cutting torque. As in the case of passive force, the smallest values were observed in the case of plates with a $V B_{\text {max wear }}=0 \mathrm{~mm}$.

Fig. 7 illustrates the effect of wear on the amplitude of the cutting torque. Significantly higher values of the cutting torque amplitude were observed during processing at $v_{\mathrm{c}}=$ $70 \mathrm{~m} / \mathrm{min}$. At higher cutting speed, and thus - rotational speed, the number of cutting edges entering the cutting zone increases, which can cause the cutting torque amplitude to decrease.

\section{Conclusions}

The impact of blade wear on reactive force and cutting torque during milling of Ti6AI4V titanium alloy is presented. The tests were carried out using new cutting inserts $\left(V B_{\max }\right.$ $=0 \mathrm{~mm})$ and used $\left(V B_{\max }=0.15 \mathrm{~mm}, 0.30 \mathrm{~mm}\right.$ and 0.45 $\mathrm{mm}$ ). Two cutting speeds were used: $v_{\mathrm{c}}=70 \mathrm{~m} / \mathrm{min}$ and 250 $\mathrm{m} / \mathrm{min}$.

The following conclusions have been drawn:

- During machining at $v_{\mathrm{c}}=70 \mathrm{~m} / \mathrm{min}$ to the wear value $V B_{\max }=0.30 \mathrm{~mm}$, with increasing wear, an increase in reactive power is observed. However, when machining with $V B_{\max }=0.45 \mathrm{~mm}$ wear plates, a decrease in the reactive power value was observed in comparison to the $V B_{\max }$ wear plates $=0.30 \mathrm{~mm}$.

- During machining at $v_{\mathrm{c}}=250 \mathrm{~m} / \mathrm{min}$, the maximum reactive force $(F=515 \mathrm{~N})$ was observed with $V B_{\max }=0.15$ $\mathrm{mm}$, and the increase in wear caused a decrease in reactive power.

- Machining with velocity $v_{\mathrm{c}}=250 \mathrm{~m} / \mathrm{min}$ is characterized by higher values of reactive power amplitude in comparison to machining with velocity $v_{\mathrm{c}}=70 \mathrm{~m} / \mathrm{min}$.

- In the range of increased wear values $\left(V B_{\max }=0.30 \mathrm{~mm}\right.$ and $0.45 \mathrm{~mm}$ ) lower torque values were recorded at a higher cutting speed.

- Significantly lower values of the breaking moment amplitude were observed during machining at $v_{\mathrm{c}}=250$ $\mathrm{m} / \mathrm{min}$ compared to the lower cutting speed.

\section{REFERENCES}

1. Burek J., Żurawski K., Żurek P. „Analiza składowych siły skrawania i naprężeń w warstwie wierzchniej metoda elementów skończonych w obróbce stopu tytanu Ti6Al4V". Mechanik. 8-9 (2015): pp. 720/37-45.

2. Huang P.L., Li J.F., Sun J., Zhou J. "Study on performance in dry milling aeronautical titanium alloy thin-wall components with two types of tools". Journal of Cleaner Production. 67 (2014): pp. 258-264.

3. Kuczmaszewski J., Zaleski K., Matuszak J., Pałka T., Garwacki R. „Wpływ średnicy frezu na jego zużycie podczas obróbki stopu tytanu Ti6Al4V". Mechanik. 3 (2017): pp. 198-200.

4. Kuczmaszewski J., Zaleski K., Matuszak J., Pałka T., Mądry J. "Studies on the effect of mill microstructure upon tool life during slot milling of Ti6Al64V alloy parts". Eksploatacja i Niezawodność- Maintenance and Reliability. 19, 4 (2017): pp. 590-596.

5. Lebaal N., Nouari M., Ginting A. "A new optimization approach based on Kriging interpolation and sequential quadratic programming algorithm for end milling refractory titanium alloys". Applied Soft Computing. 11 (2011): pp. 5110-5119.

6. Niesłony P., Habrat W. „Badania eksperymentalne oraz symulacje MES dla różnych modeli konstytutywnych procesu frezowania stopu Ti6Al4V". Mechanik. 8-9 (2014): pp. 730/63-72.

7. Oczoś K.E. Kształtowanie ubytkowe tytanu i jego stopów w przemyśle lotniczym i technice medycznej. Część l”. Mechanik. 8-9 (2008): pp. 639-656.

8. Sieniawski J. "Nickel and titanium alloys in aircraft turbine engines". Advances in Manufacturing Science and Technology. 27, 3 (2003): pp. 23-33.

9. Vijay S., Krishnaraj V. "Machining parameters optimization in end milling of Ti-6Al-4V". Procedia Engineering. 64 (2013): pp. 1079-1088.

10. Wang Z.G., Rachman M., Wong Y.S., Li X.P. "A hybrid cutting force model for high-speed milling of titanium alloys". Annals of the CIRP. 54, 1 (2005): pp. 71-74.

11. Zaleski K., Matuszak J. „Badania porównawcze wpływu parametrów technologicznych frezowania wybranych stopów tytanu na moment skrawania i chropowatość obrobionej powierzchni”. ZN Politechniki Rzeszowskiej. 295. Mechanika. 89. RUTMech, Vol. XXXIV, Iss. 89 (4/17): pp. 563-572.

Translation of scientific articles, their computer composition and publishing them on the website www.mechanik.media.pl by original articles in Polish is a task financed from the funds of the Ministry of Science and Higher Education designated for dissemination of science.

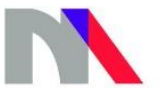

Ministry of Science and Higher Education Republic of Poland 